This is the final peer-reviewed accepted manuscript of:

Bucaria, Chiara (2018) "Genetically modified TV, or the manipulation of US television series in Italy," PERSPECTIVES 26, pp. 930 - 945.

The final published version is available online at:

http://dx.doi.org/10.1080/0907676X.2017.1407349

Rights / License:

The terms and conditions for the reuse of this version of the manuscript are specified in the publishing policy. For all terms of use and more information see the publisher's website. 
Genetically modified TV, or the manipulation of US television series in Italy

Chiara Bucaria

Department of Interpretation and Translation, University of Bologna, Forli, Italy

C.so della Repubblica, 136 - 47121 Forlì, Italy

chiara.bucaria@unibo.it

Chiara Bucaria is Associate Professor of English Language and Translation at the Department of Interpretation and Translation of the University of Bologna. Her main research interests include the translation of audiovisual products, censorship and textual manipulation, dark and taboo humour. 


\title{
Genetically modified TV, or the manipulation of US television series in
} Italy

\begin{abstract}
Although a considerable amount of research has been carried out in the field of global media studies on the ways in which US television and audiovisual products in general travel to different countries, little attention continues to be paid to the cultural and linguistic adaptation that such cross-cultural transfer inevitably requires and to the modifications to which these products become subject in the process. This paper focuses on the adaptation into Italian of a number of recent US television series containing controversial language and potentially disturbing themes such as references to death, disability, sexuality/homosexuality, and drugs. By analysing dubbed, subtitled, and fansubbed versions of such series, this study shows how the dubbed versions of the series tended to be toned down as far as taboo language and subjects are concerned, as opposed to the fansubbed versions and to some extent the official subtitles. In some of the more extreme cases the series seem to have undergone a "genetic modification" of sorts, with Italian viewers watching sometimes radically different shows with respect to their US counterparts.
\end{abstract}

Keywords: dubbing, subtitling, fansubbing, audiovisual translation, television series, manipulation, censorship

\section{Introduction}

On July 8th, 2016 the Italian state-owned network RAI2 aired the first episodes of the ABC TV series How to Get Away With Murder (from now on HTGAWM), in which a male homosexual sex scene had been edited out. This sparked the outrage of one of the actors in the scene, Jack Falahee, and of series creator Peter Nowalk and producer 
Shonda Rhimes, who all took to Twitter to express their bewilderment and to post the scene as it was originally intended. Apparently, heterosexual sex scenes had not undergone the same treatment. RAI2 issued an apology on both Twitter and Facebook, promising to air the full version the following day. Ilaria Dallatana, director of RAI2, also issued a longer statement in Italian in which she denied that censorship played any part in the incident (Shonda Rhimes had used the word in her tweet). Seemingly attempting to distance herself and RAI2 from the incident, Dallatana blamed "un eccesso di pudore dovuto alla sensibilità individuale di chi si occupa di confezionare l'edizione delle serie per il prime time," roughly "an excessive amount of modesty due to the individual sensitivity of the person(s) who produces the series for prime time." This anecdote offers an apt starting point for an illustration of the kind of manipulation taking place in audiovisual translation (AVT) in Italy, as it exemplifies many of the issues at play. Firstly, malicious manipulation of the source material was firmly denied and responsibility was placed on a single "rotten apple" rather than on systemic network policies. Incidentally, even if this were the case, the situation would be equally worrying, because it would confirm the randomness of the adaptation process and the lack of objective, shared parameters that go beyond individual people deciding what viewers are ready to see and/or hear on television. Secondly, and connected to the first issue, is a sense of secrecy and unaccountability as far as the adaptation and subsequent airing of foreign audiovisual products are concerned. In other words, viewers are normally not informed that the series they watch in Italian might not

\footnotetext{
${ }^{1} \mathrm{http}: / / \mathrm{www}$. repubblica.it/spettacoli/tvradio/2016/07/09/news/i_social_protestano_con_raidue_per_i_tagli_omofobi_in_le_regole_ del_delitto_perfetto_1_azienda_solo_pudore_-143761567
} 
correspond exactly to the version that was broadcast in their country of origin, therefore, if nobody notices any differences these practices are not usually brought to the public's attention. RAI2 issued an apology because the incident reached the stars involved in the original series and was amplified by social media to the point that measures had to be taken to avoid a PR disaster. Arguably, RAI2 would have been unlikely to issue an apology had they not been "found out."

Lastly, the reference to prime time in Dallatana's statement also appears to be particularly telling. While in Italy $H T G A W M$ is broadcast at $9 \mathrm{pm}$, the series is normally aired at $10 \mathrm{pm}$ in the US. While both $\mathrm{ABC}$ and RAI2 are national networks that have to abide by stricter regulations when to it comes to profanity and the representation of sensitive subjects, prime time in the US goes from 8 to $10 \mathrm{pm}$, thus placing $H T G A W M$ right after the watershed. This allows the series a little more freedom than if it were aired earlier in the evening. Therefore, by scheduling the series at the beginning of Italian prime time, the Italian broadcaster already implicitly altered the way in which the show was intended to be enjoyed, specifically by addressing a potentially different audience that might also include children. Hence the need to (re)package the series that Dallatana was referencing. The importance of scheduling when audiovisual products are exported to different countries is often overlooked but it's a factor that can significantly impact the success and/or perception of a series (see Barra, 2012). ${ }^{2}$

This incident is neither the first nor the last example of the manipulation that routinely occurs in the adaptation of audiovisual products, perhaps confirming the importance of the foreign distribution of such products as a crucial yet often neglected

${ }^{2}$ The Simpsons is a famous case in which its afternoon scheduling in Italy mistakenly reinforced its initial perception as a children's show. 
step in making meaning and transforming texts (Bielby \& Harrington, 2006). In fact, the anecdote above is just the more visible tip of a mostly concealed iceberg, in which forms of manipulation affect not just the images but also - more subtly - the dialogue on screen. Issues concerning the adaptation of what could potentially be perceived as taboo or offensive elements in audiovisual products have become more and more relevant, as we have recently witnessed an increase in the use of both taboo language and subjects in both mainstream and more niche TV series. Roughly since Sex and the City and The Sopranos premiered on HBO in the late 1990s, edginess and explicitness have become desirable qualities in both comedy and drama television fiction, with some of the most critically acclaimed TV series featuring potentially controversial language and themes (Bucaria and Barra, 2016). These elements, however, are not simply ancillary to the storylines, but they are part and parcel of the innovative and distinctive core of these series and moving forces in plot development and characterization. After all, what would Selina Meyer from Veep be if stripped of her insensitivity and foulmouthedness? What would The Wire be without its nitty-gritty portrayal of Baltimore, or Orange Is The New Black without its realistic prison sex scenes and racial tensions? From a global television perspective, one might wonder what happens when similar series are exported to different countries and have to be adapted and mediated for different audiences and for different broadcasting systems. If it is reasonable to argue with the Manipulation School (e.g. Hermans, 1985; Lefevere, 1992) that manipulation is inherent in translation because the process involves an interpretation by a specific person (the translator/s) and the need to adapt texts to a specific culture in a specific historical context, the kind of modification that occurs in some translated TV products - perhaps more so in serial television than in art-house films - seems to be going well beyond a run-of-the-mill adaptation or rewriting and to be moving, in the 
worst cases, onto some sort of "genetic alteration". One could even surmise that this manipulation affects the "genetic code" of the original shows to the point that the final translated product appears to be sometimes substantially different from its Englishlanguage version, thereby altering the intention of the show's creator or showrunner, and writers.

Although the influence of ideology on translation (e.g. Calzada-Perez, 2003; Tymoczko \& Gentzler, 2002) and the manipulation occurring in audiovisual products (e.g. Bianchi, 2008; Bucaria, 2007, 2008, 2009; Chiaro, 2007; Diaz Cintas, 2012; Ranzato, 2016) have been well documented, I would like to further complicate these issues by adding a few specifications. The first concerns the choice of the umbrella term "manipulation" to describe these phenomena rather than "censorship" or "censoring," which have been previously used elsewhere. Although Allan and Burridge (2006) offer a helpful distinction between censorship vs. censoring - where the former designates institutionalised, ideological bowdlerization and the latter other, more encompassing forms of censoring - I still find that "manipulation" is better suited to cover the range of possible factors that can lead to modifications in audiovisual products, including for example censoring from various agents in the translation/adaptation/localization process, self-censorship, or cases in which manipulation occurs for more technical reasons, such as lip synch in dubbing or the need for condensation and reduction in subtitling.

The second specification is that existing studies on manipulation or censorship in AVT in Italy so far have mainly focused on dubbing, which is traditionally the most widely used mode in this country and still the predominant one on Italian television. However, other forms of linguistic and cultural adaptation are also starting to be offered 
through both official and unofficial platforms. For example, in addition to the subtitles often present on the series' DVD box sets, FOX (a subscription-based channel in Italy) now offers series in both dubbed and subtitled versions, and amateur subtitling - or fansubbing - has become increasingly popular with technologically savvy television consumers. In this scenario, multiple translated versions adapted through different modes of AVT come to coexist within a relatively short time of the release of TV series and this situation allows for a more thorough and up-to-date comparative analysis of multiple versions destined to different outlets and, therefore, audiences. Incidentally, this is an interesting difference between AVT and other forms of translation of popular fiction, as normally in other cases only one translated version tends to exist of the same material when it is first published, although retranslations obviously can and do occur over time.

These relatively new AVT forms can offer interesting insights into the treatment of taboo elements when it comes to linguistic and cultural adaptation. Specifically, does this sort of "genetic manipulation" still occur in subtitles and fansubs? Or do the different modes and audiences they cater to allow for a closer representation of the shows' DNA? This paper addresses these issues by offering examples from recent TV series in which controversial language and themes have been sanitised in the dubbed version and by comparing them to their subtitled and fansubbed counterparts that have been made available, respectively, on DVD and on the websites of two of the main Italian fansubbing communities, Italian Subs Addicted or ITASA (https://www.italiansubs.net) and Subsfactory (http://www.subsfactory.it).

\section{The study}


Before delving into the comparative analysis of a few examples, it is worth offering a quick overview of the AVT modes discussed in the following sections:

- dubbing - for historical and cultural reasons and despite a somewhat more recent diversification, dubbing is still the most widely used form of AVT in Italy, particularly for films and TV shows. Dubbing is an expensive process, which involves a large number of people and normally starts with a rough translation of the dialogue, which is then modified and adapted to the lip movements on screen and then acted out by dubbing actors under the supervision of a dubbing director. Dubbing is also usually seen as being mostly domesticating in nature if not prone to censorial intervention, given the possibility it offers to potentially "disguise" the original dialogue under the superimposed target-language soundtrack.

- subtitling - subtitling, a relatively inexpensive process by which a reduced, written, target-language version of the dialogue is placed (usually) at the bottom of the screen, was until recently mainly used for art house films and on DVDs. As of late, however, subtitling has made its way to SKY Italia, Netflix and other on demand platforms, as well as the movie theatre as an alternative to dubbing. Subtitling is normally seen as a more "transparent" way of mediation of on screen content, as viewers simultaneously have access to the source-language dialogue and its target-language written and abridged version.

- fansubbing - these are subtitles created by fans, usually for fans. It's an alternative to the officially produced subtitling and it is usually made available very quickly after a TV series or film is released. Fansubbing caters to die-hard fans of a specific TV series, for example, who want to get as many details about the show as possible, and therefore it complies to completely different rules 
from "official" subtitling. Fansubbing can also be seen as a form of resistance

(Nornes, 2007) against the status quo of (poorly executed) dubbing and as a revolutionary way of returning the target text to its original core.

Based on previous research highlighting considerable discrepancies in the dubbed and subtitled versions of the same audiovisual products - particularly when it comes to the adaptation of taboo language and taboo subjects (Bucaria, 2005, 2007, 2008) - in the present study I set out to analyse the pilot episodes of eight US television series that contain varying degrees of taboo language and themes. The aim was to assess if and how these elements were adapted for Italian viewers through different modes of audiovisual translation. As mentioned above, the argument is that in some of these cases Italian audiences are exposed to target-language versions of these TV shows that are so different from the English version that we can look at this phenomenon as a sort of genetic modification that these series undergo when they cross borders. In these cases, some of the elements that make up the distinctive characteristics of the US series - their DNA if you will - were for some reason modified. While in the past Italian dubbing has often been bashed for its sometimes overly domesticating approach (see the infamous and often-quoted examples of The Nanny / La Tata and Roseanne / Pappa e Ciccia, in which both female leading characters inexplicably became immigrants from Central/Southern Italy), it is important to understand that manipulation still occurs at a perhaps more subtle level and that the manipulation of taboo language and elements is sometimes responsible for an Italian target version that is arguably quite divergent from a TV series' English-language counterpart. 
The series included in this study are listed in Figure 1, which also shows the series' collocation in the US and Italy: ${ }^{3}$ United States of Tara, The Big C, Nurse Jackie, Dexter, Breaking Bad, Six Feet Under, Californication, and True Blood. The series were selected based on the presence of taboo language and content in general. ${ }^{4}$ Also, the selected series had to be relatively recent (they cover the 2000s and beyond) and had to be available on DVD at the time of the study, so that the officially released subtitled version could be analysed as well.

Figure 1. List of TV series included in the study.

The English versions of the pilot episodes were compared to their dubbed, subtitled, and fansubbed versions released on Italian Subs Addicted (ITASA) and Subsfactory (Figure 2).

Figure 2. List of available episodes.

\footnotetext{
${ }^{3}$ Most of these shows were aired in the dubbed version first on digital or satellite subscription channels and then later migrated to free channels. Some of the Italian channels do not exist anymore but were included for the sake of completeness.

${ }^{4}$ Despite their content, the Italian DVDs of six of the series carry the generic rating " $\mathrm{T}$ - per tutti" ("for everyone"), which corresponds to the UK's British Board of Film Classification's (BBFC) rating "U - Universal" and the US's Motion Picture Association of America's (MPAA) rating “G - General.” Nurse Jackie, on the other hand, did not carry a specific rating, while Six Feet Under was rated unsuitable for viewers under 14 years of age.
} 
Whenever possible, the English-language version was compared with 4 different Italian versions: the dubbed and subtitled DVD versions, and the fansubbed versions from the two platforms mentioned above, ITASA and Subsfactory. In some cases, not all of these were available and in two particular cases the DVD only offered what are sometimes called "dubtitles" - i.e. subtitles that were just a reduced version of what viewers hear in dubbing - which were therefore not taken into consideration. The DVD versions of the TV series were preferred to the TV broadcasts specifically because they are easier to find than the latter, which in some cases date back to over 10 years ago. As already noted with $H T G A W M$, however, the broadcast versions are bound to have different restrictions than the DVDs as far as taboo language and content are concerned and this discrepancy could offer further material for future analyses.

By way of a disclaimer, it should be noted here that I was not interested in a prescriptive analysis of these forms of AVT - for example, as has been the case with earlier studies in this discipline, by claiming the superiority of subtitling over dubbing or by demonizing fansubbing as subtitling's “evil twin." Furthermore, the point was not to evaluate the quality of these versions in absolute terms, as they all had mistakes and/or inaccuracies, but rather to selectively look at the strategies they used as far as the rendering of taboo was concerned.

\section{Results and analysis}

Unsurprisingly, in general terms the dubbed versions were normally toned down both in terms of swearing/blasphemy and references to taboo subjects. DVD subtitles (where available) were closer to the English version both in terms of swearing/blasphemy and 
taboo subjects, while the fansubbed versions were closer in all respects to the English version and, overall, more literal in their translation choices.

If we wanted to position these three modes of AVT on a continuum that extends between the two opposite poles of source- and target-oriented rendering, based on the sample at hand I would propose the scheme in Figure 3, in which the target-oriented end represents major manipulation of the English-language material, while the sourceoriented end implies closer adherence to the taboo language and references found in English. On this continuum dubbing would appear to be closer to the target end, fansubbing at the opposite extreme, and DVD subtitling somewhere in the middle but closer to the source end.

Figure 3. Position of the AVT modes on the source-target continuum.

In the sample analysed here, the dialogue in the dubbed versions is sometimes heavily manipulated, with the Nurse Jackie and Six Feet Under ${ }^{5}$ pilot episodes being the most "genetically modified." The following sections will comment on specific examples from the sample by looking at three different categories of potentially controversial content: $\mathrm{i}$. dysphemistic language, ii. ideological elements, and iii. humour. Admittedly, these are fuzzy categories and a certain amount of overlap is to be expected - for example, taboo language may or may not be used to express taboo and/or humorous content, and

\footnotetext{
${ }^{5}$ When Six Feet Under was aired on national TV in Italy, users in online discussion forums complained not only about the manipulation in the dialogues but also about "controversial" scenes (mainly involving male homosexual sex) being edited out.
} 
ideological reasons might be at the root of the toning down of dysphemisms - therefore they are to be interpreted as working categories.

\section{Dysphemistic language}

Under the heading "dysphemistic language," which I borrow from Allan and Burridge (2006), I include both swearwords and blasphemy. In general, a certain level of inconsistency was found in the way in which dysphemisms were rendered. For instance, as mentioned above, Nurse Jackie and Six feet Under are heavily manipulated, whereas Californication and Breaking Bad are less so. In general, ass very frequently becomes "sedere" ("butt") and Jesus, Jesus Christ, Christ, and damn are either omitted or toned down. Shit, shitty and fucking are often removed when they occur in adjective position and when they have an expressive function, but less frequently so when they retain their literal meanings, although it should be noted that in the case of subtitling omissions might have occurred simply because of space/time constraints.

The following is an example from True Blood, in which Lafayette, an AfricanAmerican, very effeminate and foul-mouthed gay character working at the local bar, jokingly interacts with some of the waitresses. As often happens with Lafayette, the conversation revolves around sex:

Arlene: Do you even know what's between a woman's legs?

Lafayette: I know every man, whether straight, gay, or George ma-fuckin’ Bush is terrified of the pussy.

Table 1.

While the two fansubbed versions kept closer to the vulgar language with the expressions "stronzo" and "testa di cazzo" (respectively "asshole" and "dickhead") 
referring to George Bush and "figa" and its variant "fica" for pussy, the dubbed version chooses to use euphemisms - specifically with the expressions "figlio di buona donna" (roughly "son of a gun" in AE) and "passera" for the female organ - which arguably do not retain the expressive impact of the English version. This is a typical case in which swearing and vulgar language in general help characterization, especially in the first episode of a TV series, whose aim is to outline the main characters and their idiosyncrasies. We know for a fact that in the English version Lafayette is not the kind of person who censors himself through the use of euphemisms. Therefore, the dubbed version can be seen as causing a misrepresentation of this character by not reproducing the strength, expressiveness, and creativity of his language in Italian. In the case of the use of the euphemism "passera," it should be noted, however, that the possibility exists that this solution might have been chosen for lip-synch reasons, as Lafayette's lip movements would more easily justify the initial plosive /p/ sound in "passera" than the fricative consonant in "figa."

Lafayette is not the only example of a character who is strongly connoted by his language: others include Debra Morgan in Dexter, Tara in True Blood, Jesse Pinkman in Breaking Bad, occasionally Federico in Six Feet Under, and one of Tara's personalities in United States of Tara. It is therefore easy to see that if a large portion of a character's profanities is omitted, we also risk eliminating some important traits of his/her personality.

Jackie in Nurse Jackie is another interesting example of a character lacking much of the edginess that makes her such a unique and conflicted character in English. In the following example Jackie reprimands the young and arrogant Dr Cooper for misdiagnosing a patient that died as a direct result of this. 
Table 2.

While the two fansubbed versions kept the vulgar language, the dubbed version chose to omit it altogether. Jackie's line is delivered in Italian in a firm and resolute tone but what she says sounds more like a milder warning to Dr Cooper to be more careful rather than an angry order to stay out of her way and not create problems. Generally speaking, the impression one gets is that playing down Jackie's language falls in line with the perceived expectations that Italian viewers might have towards people - and especially women - in the medical profession, who are likely expected to always be caring and motherly, and certainly not to behave like Jackie, who is rather matter-of-fact and abrasive, and, as a painkiller addict, a morally questionable character as well. As further confirmation, a similar approach can be found in the adaptation of House $M D$, in which Dr House's language is toned down - even despite the objective lack of swearwords per se - particularly in connection with the abrasive way he addresses his patients. For example, in the pilot episode of the series while visiting a patient whose skin has suddenly become orange because of his overuse of carotene Dr House exclaims "You're orange, you moron! - Non lo vede che è tutto arancione? (Can't you see you're all orange?). Here and elsewhere in the series the deletion of the minor epithet "moron" in the Italian version, for which many alternatives would actually have been possible (e.g. cretino, deficiente, idiota), is probably due to the lack of correspondence between Dr House's attitude and language and the way "normal" doctors treat their patients, that is ideally with respectful tact. This choice may indicate that "genetic modification" is happening and that perhaps underlying ideological issues are another factor playing into the choice of sanitizing dysphemistic language. 
Another telling example from the sample is the only occurrence of what is generally regarded as the most of dysphemistic expression in English, cunt - or, euphemistically, the "C word".

$$
\begin{array}{ll}
\text { Marlene: } & \text { You're a pain in the ass. } \\
\text { Cathy: } & \text { You're a fucking cunt. }
\end{array}
$$

The example is from the series The Big $C{ }^{6}$ from a scene in which the main character Cathy is arguing with her elderly and extremely bad-tempered neighbour Marlene.

\section{Table 3.}

The shock value in this example is conveyed not only by the word cunt and by its intensifier fucking but also by the context of the line's delivery. In fact, the line is spoken in a rage by a younger woman towards an elderly - although admittedly very discourteous - woman, therefore the age difference between the characters and the lack of the socially preferred respectful attitude towards the elderly add to the strength of the scene. As a result, the dubbed version cannot ignore the dysphemistic expression completely and has to find a solution to justify the angered behaviour of the two women on screen. The dubbed version offers "vecchia stronza" ("old bitch"), where the modifier "old" foregrounds the age difference between the two and reinforces Cathy's

\footnotetext{
${ }^{6}$ The title euphemistically plays with the allusion to another unmentionable word beginning with C, "cancer."
} 
disrespectful language and behaviour. The subtitled version opts for a version of this with the equivalent of "real bitch". The fansubbed version, on the other hand, prefers a stronger solution in Italian - "una troia del cazzo" ("a fucking whore/bitch"), which, although semantically slightly off-point perhaps indicates the translator's attempt to find an equally powerful expression in Italian. It is also worth noting that, unlike the dubbed and subtitled versions, the fansubbed version uses the "tu" form (the informal "you") as a form of address between the two women, which by contravening to the rule by which the formal "lei" is usually used between strangers possibly emphasizes even more the breaking of linguistic taboos and conventions in this scene.

In all fairness, the lack of a completely overlapping insult in Italian might also have played a part in the weaker rendering in the dubbed and subtitled versions. However, the solutions offered in the fansubs by ITASA confirms that alternative, more offensive turns of phrases would have been available in Italian as well. The fansubbed version also appears to have remained closer to the English version in translating the expression pain in the ass in Marlene's line, whereas the dubbed and subtitled versions used the euphemisms "rompiscatole" and "scocciatrice" (roughly "pain in the neck", “nuisance").

\section{Ideological manipulation}

While, as mentioned above, the reasons for manipulation in AVT may be manifold, this section focuses on cases in which specific ideological approaches to the source material seem to be the most likely explanation for a modified target version in Italian. These include examples of manipulation occurring perhaps in order to mask uneasiness on the part of the translators/adaptors/broadcasters with some questionable choices and/or behaviour depicted on screen. In the sample at hand Six Feet Under and Nurse Jackie 
were the shows in which the largest amount of manipulation was present, not only in terms of dysphemisms but also taboo elements in general, such as references to sex and sexuality, drug use, and death.

In the following example from the very beginning of the Six Feet Under pilot episode Ruth Fisher is talking to her son David, who we later learn is a closet gay man, about her husband's midlife crisis:

Table 4.

As we might have expected, while the subtitled and fansubbed versions keep the reference to homosexuality, this is wiped out completely in the dubbed version. Apart from being a very evident omission of information in the source text, this choice does not take into consideration the dynamics at play within the Fisher family. David has not come out to his family yet, therefore the fact that his mother expresses negative comments on homosexual people or behaviour is intended to set the scene for some further developments in the series. As a consequence, if viewers are not given that piece of information they will miss significant insight into the characters' psychology. Furthermore, it should be noted that the reference to a "hearse" was also omitted in the dubbed version, thus incidentally missing the opportunity for humour inherent in the cliché association between a man's midlife crisis and the purchase of a new hearse (instead of a new car). This apparent attempt to downplay the death theme seems even more off point as the series famously takes place in a funeral home.

The following is another example of what looks like ideological manipulation in Nurse Jackie. In this scene Jackie is talking to the dead body of a young bike messenger, while forging his signature on his organ donor's card. 
Table 5.

While the two fansubbed versions keep closer to the meaning of the source text (except for what looks like a misinterpretation in the version provided by ITASA), the dubbed version adds an apologetic attitude on Jackie's part and an acknowledgement of her behaviour being wrong ("I was hoping not to get to this" and "it's wrong"), which were not there in the English dialogue. Once again, this seems to fall in line with the condescending expectation that certain kinds of behaviour are inappropriate for nurses especially for those working at a Catholic hospital - therefore Jackie should at least express regret for her behaviour.

\section{Humour}

The manipulation of taboo elements or language was also found to affect the successful rendering of humour in the series analysed, which in most cases contain an interesting mixture of drama and comedy, so much so that it is sometimes difficult to categorise them. Most of them offer some sort of edgy, unconventional, or even dark humour that represent an integral part of their DNA and that, if not successfully conveyed in the target language, might impact the audience's perception of said series.

In this example from Six Feet Under an elderly man, who is presumably the deceased's husband or close relative, looks down at a woman in a coffin at what we presume is her funeral wake:

Table 6. 
The humour clearly relies on the contrast between the formality and somberness of the funeral setting and the use of the dysphemistic word shit, or, in broader terms, between people's expectations in similar circumstances and the upending of those expectations. Apart from being a widely used strategy to create humour, incongruity is also a very common device in Six Feet Under, which often relies on dark and off-kilter comedy. The subtitled and fansubbed versions keep the swearword by using the closest equivalent Italian ("merda"), while in the dubbed version we have a blatant attempt at toning down the language by using the word "sterco" instead. In the case of the dubbed version the verbal vs. situational contrast is still there, but the impact and the humorous effect are much weaker than in the two other versions. Since, as many of the other series in this study, Six Feet Under heavily relies on the breaking of taboos even when it comes to humour, one cannot help but wonder whether "genetic modification" might be at play here.

Finally, in this scene from Californication the protagonist Hank, a Bukowskiesque type writer, is in bed with a woman who is complaining that her husband never gave her an orgasm.

Woman: $\quad[\ldots]$ he spent 45 minutes trying to find my clit.

Hank: $\quad$ How did he do?

Woman: I'm pretty sure he thinks it's in the bottom.

Hank: $\quad$ Near the vaganus? That's weird.

Obviously humour derives from the use of the blend word "vaganus," which reflects Hank's verbal creativity throughout the show and, together with his irreverent humour, is one of his more distinctive features. 
Table 7.

None of the four translated versions attempted at recreating a humorous blend word in Italian: the dubbed version and the fansubbed version from Subsfactory opted for one or the other parts of the anatomy ("near the anus" or "near the vagina" respectively), while the other fansubbing website chose "near the other hole," not mentioning either the vagina or the anus. Regardless of the objective difficulty of finding a more creative equivalent in Italian in the short time usually allowed to translators/adaptors, the solution offered in the dubbed version is reminiscent of the strategy used in the previous example from Six Feet Under, in which the use of a higher register word created a similar drop in the humorous effect. In this case the scientifically accurate term "anus" was preferred to a more slangy or playful alternative, which was instead used in the DVD subtitles ("bernarda") and in the ITASA version ("l'altro buco").

\section{Concluding remarks}

From the admittedly small albeit representative collection of examples analysed above it appears clear how the dubbed versions of the eight pilot episodes in the study tended to be toned down as far as taboo language and subjects are concerned, as opposed to the fansubbed versions and to some extent the official subtitles available on DVD. In some of the more extreme cases the series seem to have undergone a "genetic modification" of sorts, with Italian viewers watching sometimes radically different shows with respect to their US counterparts.

More research is needed in terms of the possible differences existing between the DVD versions of these series as opposed to their broadcast counterparts (not analysed here) and of the non-linguistic forms of manipulation that could not be addressed here 
for reasons of space. However, whatever the pattern was that led to manipulation in the series taken into consideration in this study, it appears clear that our analysis cannot stop at the micro-level - i.e. the comparative, textual one - but should expand to include broader considerations, not least the status that these forms of popular fiction enjoy in the target culture and whether or not the diminished perception of their authorship and value as artistic endeavours might be at the basis of their being seen mainly as commercial entities and, as such, as more easily manipulable. Furthermore, as often happens with popular fiction, other factors influencing these choices might be linked to genre and audience considerations, for example with comedy traditionally enjoying a lesser status than drama, and female and/or teenage viewership negatively affecting the perception of some television products (Caughie, 2012).

In terms of the factors impacting the way in which different modes of AVT work, going back to the idea of the continuum between source- and target-oriented solutions, the increased presence of manipulation in dubbing with respect to other forms of AVT may be traced back to a number of different reasons, some of which can be reconnected to broader, extratextual issues. First and foremost, there is the difference between the American and the Italian broadcasting systems, with the Italian system probably being less layered than the American one. For example, while in the US a premium cable option allows channels such as $\mathrm{HBO}$ and Showtime to address their distinctively taboo-breaking programming to a relatively niche audience, in Italy those same series will be adapted for and watched by a proportionally wider audience than the one that watches those shows in the US. Indeed, as in Italy many series are aired first on subscription-based platforms and are subsequently also made available on free, national networks, this means that when they are first dubbed their adaptation of taboo content 
will have to cater to the lowest common denominator, i.e. a wider, nationwide audience, trying to reach as many viewers and offend as few as possible in the process. ${ }^{7}$

On the other hand, fansubbing caters to niche audiences that specifically look for subtitles to their favorite TV series and who have very specific expectations on what they should be like, i.e. as detailed as possible, not censored and as close as possible to the source culture. Therefore, unsurprisingly, in this case there is much less room for "genetic modification".

DVD subtitles are somewhere in the middle between the two ends of the continuum presumably because they cater to a smaller audience of viewers who buy that specific series on DVD. In these cases, there is less of a chance that these viewers might be shocked by taboo language and subjects, since they are already familiar with the series and its themes. However, officially released subtitles presumably still have to strike a balance between the traditional space and time constraints of this form of AVT - in which, for example, dysphemisms and expressive language in general are one of the first elements to be omitted, if need be - and the increased accountability of subtitlers that comes not only with some of the viewers' better knowledge of English but also with an increased attention to fans. In fact, while fans have shown their dissatisfaction with some dubbing adaptations before, ${ }^{8}$ the digital age and social media have made fan bases more vocal about what they perceive as substandard adaptations and more entitled to more source-oriented translation in audiovisual products.

\footnotetext{
${ }^{7}$ This is of course done because re-dubbing the same TV series for different audiences would be out of the question, given the cost of dubbing.

8 "Buffy L’ACCHIAPPAvampiri: L'adattamento Italiano Di Buffy" http://www.buffymaniac.it/adattamento.php
} 
In previous research (Bucaria, 2009, 2010), I lamented the lack of objective criteria and some sort of disrespect - or disregard at best - for the "genetic core" of audiovisual products in the process of their adaptation for Italian audiences. While I still find that this is the case - especially when it comes to the slippery boundary between localization and manipulation, and the role of commissioners, distributors, and broadcasters - the outlook seems to be slightly more optimistic today. Specifically, with Netflix and other on-demand and streaming services having been recently launched in Italy, there seems to be an increased accountability for the services offered due to an increasingly competitive market. If Netflix subtitles are any indication, taboo language seems to have made its way more prominently into this mode of AVT, which has been generally impervious to dysphemisms based on the mostly unsubstantiated assumption in the industry that reading swearwords has a stronger impact that hearing them. It will be interesting to see if this trend continues, both on new and older series, as ever more demanding audiences now have access to digital video storage devices, such as DVRs, TiVo-like features such as MySky and other on-demand and streaming facilities, thanks to which translations - just like the audiovisual products they are attached to - have become more re-useable and re-watchable than ever before.

Eventually, the Italian AVT and audiovisual distribution industry will likely have to get used to the idea that even in a predominantly dubbing country like Italy all the different versions of the same audiovisual product and the different modes of AVT with the possible addition of new ones - will have to co-exist and possibly vie for viewers' attention in the future. In the best of cases this will lead to positive competitiveness through mutual influence, in the worst to the demise of the modes of AVT that are unable to keep up with the new standards. 


\section{References}

Allan, K., \& Burridge, K. (2006). Forbidden words. Taboo and the censoring of language. Cambridge: Cambridge University Press.

Barra, L. (2012). Risate in scatola. Storia, mediazioni e percorsi distributivi della situation comedy americana in Italia. Milano: Vita e Pensiero.

Bianchi, D. (2008). Taming teen-language. The adaptation of Buffyspeak into Italian. In D. Chiaro, C. Heiss, \& C. Bucaria (Eds.), Between text and image. Updating research in screen translation (pp. 183-195). Amsterdam/Philadelphia: John Benjamins. DOI: 10.1075/btl.78.19bia

Bielby, D. D., \& Harrington, C. L. (2006). Global TV: Exporting television and culture in the world market. New York: NYU Press.

Bucaria, C. (2005). The perception of humour in dubbing vs. subtitling: The case of Six Feet Under, ESP Across Cultures, 2, 36-48.

Bucaria, C. (2007). Humour and other catastrophes: Dealing with the translation of mixed-genre TV series. Linguistica Antverpiensia, New Series, 6, Audiovisual Translation: A Tool for Social Integration, 235-254.

Bucaria, C. (2008). Manipulation and creativity in the adaptation of humour: The case of Will \& Grace. Textus, 21(1), 47-64. DOI: 10.1400/96611

Bucaria, C. (2009). Translation and censorship on Italian TV: An inevitable love affair? VIAL - Vigo International Journal of Applied Linguistics, 6, Special Issue on Language, Translation and the Media (R. A.Valdeón, Ed.), 13-32.

Bucaria, C. (2010). Laughing to death: dubbed and subtitled humour in Six Feet Under. In D. Chiaro (Ed.), Translation, humour and the media (pp. 222-237). London: Continuum.

Bucaria, C., \& Barra, L. (Eds.) (2016). Taboo comedy. Television and controversial humour. Basingstoke: Palgrave Macmillan.

Calzada-Perez, M. (Ed.) (2003). Apropos of ideology. Translation Studies on ideologyideologies in Translation Studies. London: Routledge.

Caughie, J. (2012). Television and serial fictions. In D. Glover \& S. McCracken (Eds.), The Cambridge companion to popular fiction (pp. 50-67). Cambridge: Cambridge University Press. DOI: 10.1017/CCOL9780521513371.005

Chiaro, D. (2007). Not in front of the children? An analysis of sex on screen in Italy. Linguistica Antverpiensia, New Series, 6, 255-276.

Díaz-Cintas, J. (Eds.) (2012). La Manipulation de la traduction audiovisuelle / The manipulation of audiovisual translation. Special issue of Meta 57(2). 
Hermans, T. (1985/2014). Translation Studies and a new paradigm. In T. Hermans (Ed.), The manipulation of literature. Studies in literary translation. New York: Routledge.

Lefevere, A. (1992). Translation, rewriting and the manipulation of literary fame. London: Routledge.

Nornes, A. M. (2007). Cinema Babel. Translating global cinema. Minneapolis: University of Minnesota Press.

Ranzato, I. (2016). Translating culture specific references on television. The case of dubbing. London: Routledge.

Tymoczko, M. \& Gentzler, E. (2002). Translation and power. Amherst and Boston: University of Massachusetts Press.

Table 1.

\begin{tabular}{|l|l|l|l|}
\hline \multicolumn{1}{|c|}{ English } & \multicolumn{1}{|c|}{ Dubbing } & \multicolumn{1}{c|}{ ITASA } & \multicolumn{1}{c|}{ Subsfactory } \\
whether straight, & qualsiasi uomo, che & etero o gay o lo & uomo, che sia etero, \\
gay, or George ma- & sia etero, gay o & stronzo di George & gay o George “testa \\
fuckin' Bush is & figlio di una buona & Bush, è terrorizzato & di cazzo" Bush, è \\
terrified of the & donna è terrorizzato & dalla figa. & terrorizzato... dalla \\
pussy. & dalla passera. & & fica. \\
\hline
\end{tabular}

Table 2.

\begin{tabular}{|l|l|l|l|}
\hline \multicolumn{1}{|c|}{ English } & \multicolumn{1}{c|}{ Dubbing } & \multicolumn{1}{c|}{ ITASA } & \multicolumn{1}{c|}{ Subsfactory } \\
\hline What you can do & Apra bene le & Ecco quello che & Puoi fare questo \\
for me is this: you & orecchie. D'ora in & può fare: starmi & per me: puoi \\
\hline
\end{tabular}




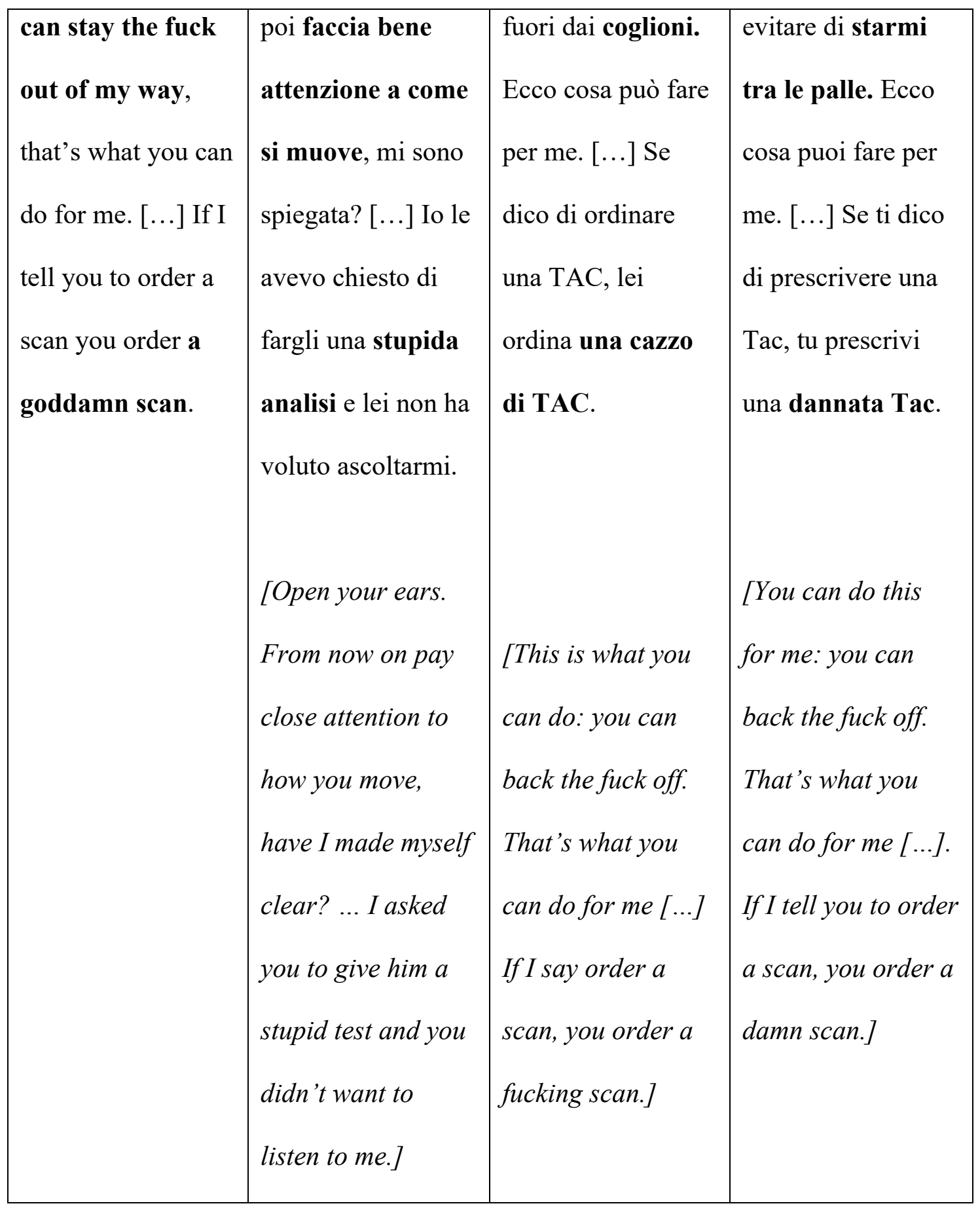

Table 3.

\begin{tabular}{|l|l|l|l|}
\hline \multicolumn{1}{|c|}{ English } & \multicolumn{1}{|c|}{ Dubbing } & DVD subtitles & \multicolumn{1}{c|}{ ITASA } \\
\hline Marlene: & Lei è una & Lei è una scocciatrice. & Sei una rottura di \\
You're a & rompiscatole. & & palle. \\
& & & \\
\hline
\end{tabular}




\begin{tabular}{|l|l|l|l|}
\hline pain in the & & & \\
ass. & & & \\
\hline Cathy: & Lei è una vecchia & Lei è una vera stronza. & Tu sei una troia del \\
You're a & stronza. & & cazzo! \\
fucking & & & \\
cunt. & & & \\
\hline
\end{tabular}

Table 4.

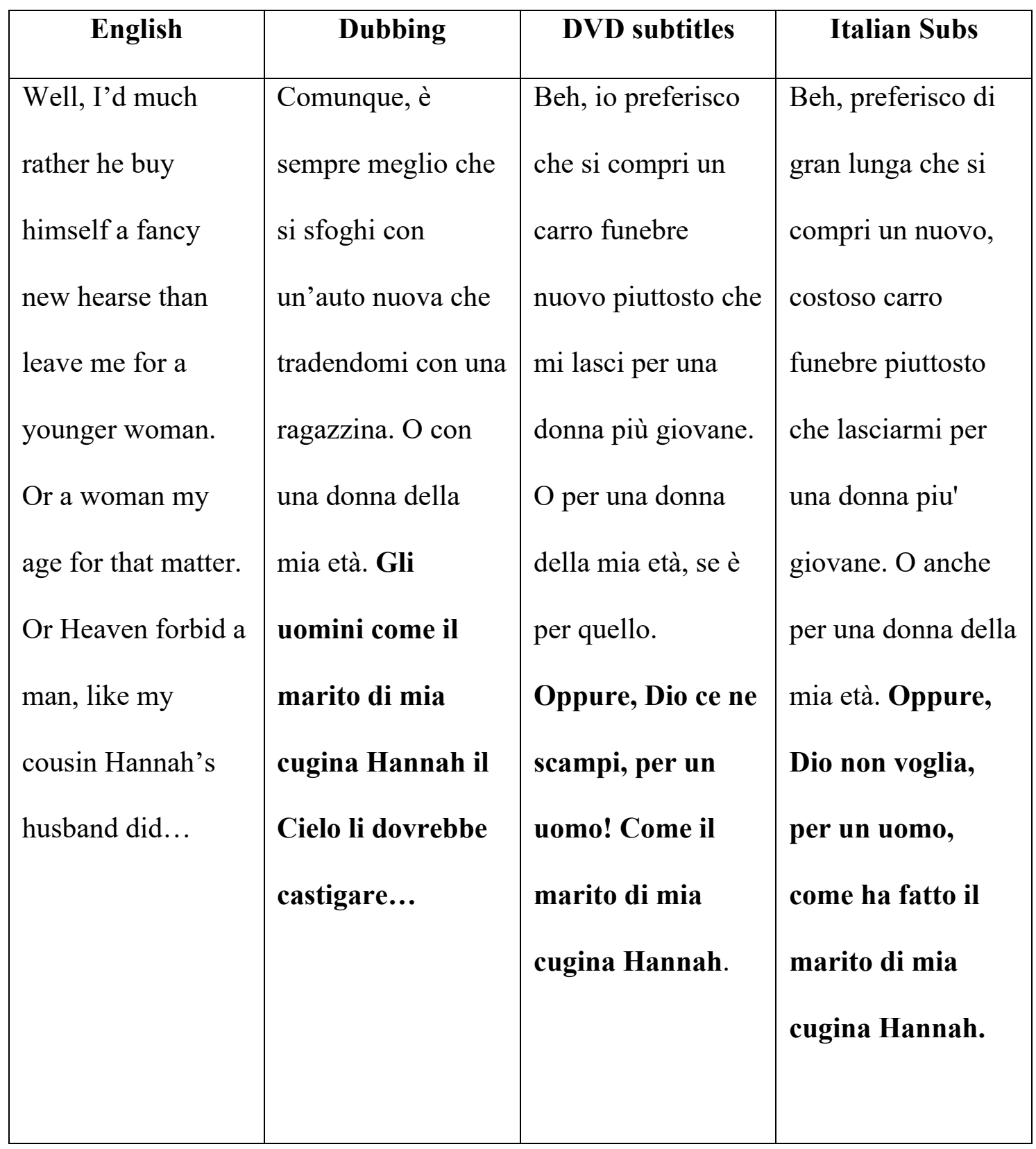




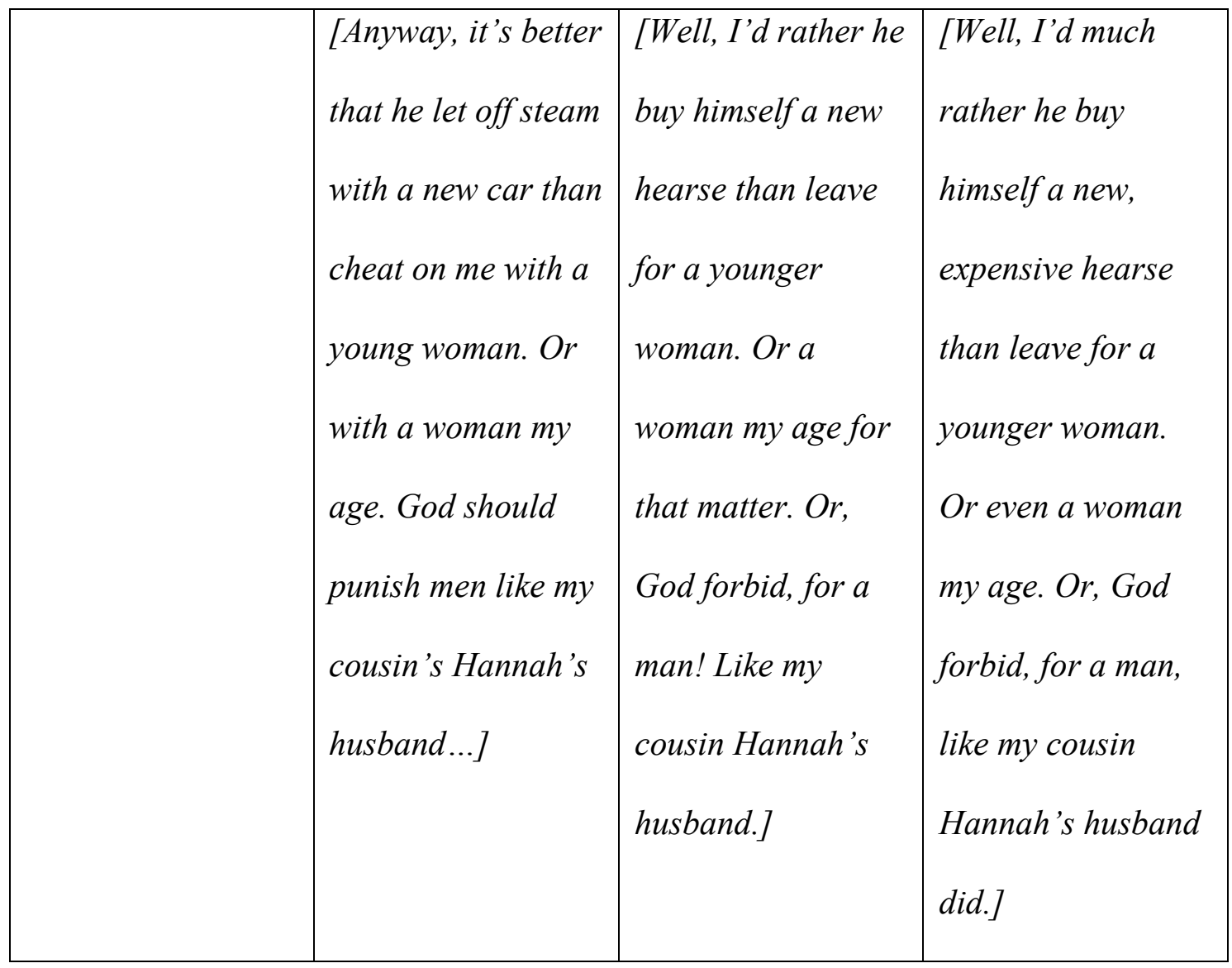

Table 5.

\begin{tabular}{|l|l|l|l|}
\hline \multicolumn{1}{|c|}{ English } & \multicolumn{1}{|c|}{ Dubbing } & \multicolumn{1}{c|}{ ITASA } & \multicolumn{1}{c|}{ Subsfactory } \\
\hline You should not & Speravo di non & Non saresti dovuto & Non saresti dovuto \\
have died, Peter & arrivare a tanto, & morire... Peter & morire, Peter \\
Michael Donovan. & Peter Michael & Michael...Donovan. & Michael Donovan. \\
It may have been a & Donovan. È & Potrà essere una & Potrà anche essere \\
shame, but it won't & scorretto, ma così & cosa di cui & stato un peccato, \\
be a waste, that I & non sarai morto & vergognarsi, ma non & ma non sarà uno \\
promise. & invano. & andrà sprecata, lo & spreco, te lo \\
& & giuro. & prometto. \\
\hline
\end{tabular}




\begin{tabular}{|l|l|l|l|}
\hline [I was hoping not & [You shouldn't have & [You shouldn't \\
to get to this. It's & died...Peter & Mave died, Peter \\
wrong, but this & Michael...Donovan. & Michael Donovan. \\
way you will not & It may be something & It may have been a \\
have died in vain.] & shameful, but it & shame/sin, but it \\
& won't go to waste, I & won't be a waste, I \\
promise.]
\end{tabular}

Table 6.

\begin{tabular}{|c|c|c|c|}
\hline English & Dubbing & DVD subtitles & ITASA \\
\hline $\begin{array}{l}\text { If there's any justice } \\
\text { in the universe she's } \\
\text { shoveling shit in } \\
\text { hell. }\end{array}$ & $\begin{array}{l}\text { Se c'è un po' di } \\
\text { giustizia } \\
\text { nell'universo, starà } \\
\text { spalando sterco giù } \\
\text { all'inferno. } \\
\text { [If there's any } \\
\text { justice in the } \\
\text { universe, she's } \\
\text { shoveling manure } \\
\text { down in hell.] }\end{array}$ & $\begin{array}{l}\text { Se c'è davvero } \\
\text { giustizia } \\
\text { nell'universo, } \\
\text { adesso starà } \\
\text { spalando merda } \\
\text { all'inferno. } \\
\text { [If there's really } \\
\text { justice in the } \\
\text { universe, she's } \\
\text { shoveling shit in } \\
\text { hell.] }\end{array}$ & $\begin{array}{l}\text { Se c'è un po' di } \\
\text { giustizia } \\
\text { nell'universo, a } \\
\text { quest'ora starà } \\
\text { spalando merda } \\
\text { all'inferno. } \\
\text { [If there's any } \\
\text { justice in the } \\
\text { universe, by now } \\
\text { she's shoveling shit } \\
\text { in hell.] }\end{array}$ \\
\hline
\end{tabular}

Table 7.

\begin{tabular}{|c|c|c|c|c|}
\hline English & Dubbing & DVD subtitles & ITASA & Subsfactory \\
\hline
\end{tabular}




\begin{tabular}{|c|c|c|c|c|}
\hline $\begin{array}{l}\text { Near the } \\
\text { vaganus? }\end{array}$ & $\begin{array}{l}\text { Cioè vicino } \\
\text { all'ano? } \\
\text { [You mean } \\
\text { near the } \\
\text { anus?] }\end{array}$ & $\begin{array}{l}\text { Vicino alla } \\
\text { bernarda? } \\
\text { [Near the } \\
\text { cooch?] }\end{array}$ & $\begin{array}{l}\text { Vicino all'altro } \\
\text { buco? } \\
\text { [Near the } \\
\text { other hole?] }\end{array}$ & $\begin{array}{l}\text { Vicino alla } \\
\text { vagina? } \\
\text { [Near the } \\
\text { vagina?] }\end{array}$ \\
\hline
\end{tabular}

